Journal of Community Based Environmental Engineering and Management, 2019, Vol. 3, No. 2: 41-48

\title{
ANALISIS KONDUKTIVITAS PADA PRODUKSI BIOFLOKULAN-DYT SEBAGAI PENGGANTI FLOKULAN SINTETIS
}

\author{
Ricky Febriyanto \\ Program Studi Teknik Lingkungan, Universitas Banten Jaya
}

\begin{abstract}
Abstrak
Penggunaan flokulan sintetis dalam proses pengolahan limbah cair dapat mengakibatkan pencemaran lingkungan. Flokulan ini relatif persisten sehingga sulit untuk terdegradasi oleh mikroorganisme. Isolasi senyawa aktif Bioflokulan-DYT yang diperoleh dari salah satu tanaman tropis Indonesia, berpotensi dapat menjadi flokulan alami pengganti flokulan sintetis. Isolasi dilakukan dengan cara direfluk menggunakan metanol sebagai pelarut, dapat menghasilkan kristal Bioflokulan-DYT sebesar 21,16 gram. Hasil pengukuran konduktivitas kristal senyawa aktif Bioflokulan-DYT diperoleh nilai hantaran molar sebesar 0,000888 mS ppm-1, 0,000786 mS ppm-1, 0,000737 mS ppm-1, 0,000688 mS ppm-1, 0,000660 mS ppm1, 0,000666 mS ppm-1, 0,000629 mS ppm-1 dan 0,000610 mS ppm-1. Data nilai hantaran molar Bioflokulan-DYT menunjukan kecenderungan penurunan seiring dengan kenaikan nilai konsentrasi senyawa aktif Bioflokulan-DYT. Pengaruh konsentrasi terhadap penurunan nilai hantaran molar pada penelitian ini, diperoleh sebesar 88,15\%. Berdasarkan analisis tersebut, Bioflokulan-DYT berpotensi dapat berinteraksi dengan ion logam, sehingga dapat digunakan sebagai pengganti flokulan sintetis dalam proses pengolahan limbah cair.
\end{abstract}

Kata kunci: bioflokulan-DYT, kristal, refluks, konduktivitas

\section{Pendahuluan}

Proses pengolahan limbah cair terdiri dari beberapa tahapan, yaitu pengolahan secara fisika, biologi dan kimia. Pengolahan limbah cair secara fisika meliputi proses sedimentasi dan filtrasi sedangkan secara biologi meliputi oksidasi senyawa organik oleh mikroorganisme. Proses pengolahan limbah cair secara kimia umumnya meliputi proses netralisasi, koagulasi dan flokulasi.

Koagulasi adalah proses destabilisasi partikel koloid oleh koagulan. Pada umumnya koagulan yang sering digunakan pada proses koagulasi

${ }^{*}$ Penulis Korespondensi:

E-mail: rickyfebriyanto@unbaja.ac.id

Diterima pertama kali: 25 Juli 2019

Direvisi : 27 Agustus 2019

Disetujui untuk publikasi: 28 Agustus 2019 adalah ferro sulfat, ferri klorida, dan alum. Sedangkan flokulasi adalah proses penggabungan flok-flok kecil untuk membentuk flok yang lebih besar dengan penambahan koagulan tambahan atau flokulan. Terbentuknya flok yang lebih besar (agregrat), akan mempercepat proses pengendapan sehingga mempermudah pengolahan sekunder selanjutnya seperti filtrasi pada limbah cair.

Flokulan yang sering digunakan di kalangan industri umumnya menggunakan polimer sintetik seperti polielektrolit kationik, polielektrolit anionik, dan polielektrolit nonionik. Namun, penggunaan polimer sintetik sebagai flokulan memiliki beberapa kelemahan. Flokulan ini relatif persisten sehingga sulit untuk terdegradasi oleh mikroorganisme. Penggunaan polimer sintetik cenderung efektif hanya pada konsenterasi kecil. Dalam jumlah yang besar, 
polimer ini membentuk flok yang tidak stabil karena tidak tahan dengan gaya geser (poor shear stability). Oleh kerena itu, seringkali endapan lumpur yang terbentuk tidak stabil, sehingga berpotensi menyebabkan kontaminasi lingkungan. Kelemahan lain dari polimer sintetik, umumnya memiliki harga yang relatif mahal dan tidak ekonomis untuk masyarakat.

Untuk mengatasi berbagai kelemahan flokulan sintetis, berbagai alternatif penggunaan flokulan yang ramah lingkungan dengan nilai ekonomis terus diteliti. Beberapa flokulan alternatif telah berhasil ditemukan dan terus dikembangkan. Salah satunya, adalah Bioflokulan-DYT. Bioflokulan-DYT merupakan polimer alami yang berasal dari salah satu tanaman tropis Indonesia. Penggunaan flokulan alami ini diyakini akan lebih mudah terdegradasi oleh mikroorganisme, sehingga penggunaannya tidak menimbulkan dampak bagi lingkungan. Selain itu, ketersediaan bahan baku Bioflokulan DYT di alam Indonesia cukup melimpah, sehingga memungkinkan untuk dapat dikembangkan menjadi komoditas yang lebih ekonomis.

Beberapa peneliti sebelumnya telah mengkaji Bioflokulan-DYT dari aspek karakteristik sifat kimia. Diketahui Bioflokulan-DYT memiliki kandungan gugus fungsi $\mathrm{O}-\mathrm{H}, \mathrm{C}=\mathrm{O}, \mathrm{C}=\mathrm{C},-\mathrm{CH}_{2}$ dan $-\mathrm{CH}_{3}$ (Ahmad. 2007). Berdasarkan data spektrum Fourier Tansform Infrared Spectroscopy (FTIR) diperoleh bentuk kristal Bioflokulan DYT baik bentuk batang maupun bentuk kotak tersusun atas gugus fungsi yang sama yaitu O-H, C-H dan $\mathrm{C}=\mathrm{O}$ (Walyadi, 2008). Selain itu menurut hasil penelitian Yosanti (2005), pada senyawa aktif Bioflokulan-DYT terdapat gugus fungsi $-\mathrm{OH}, \mathrm{C}=\mathrm{O},-\mathrm{CH}_{2}$, dan $\mathrm{C}-\mathrm{O}$ serta zat aktif yang dihasilkan termasuk kedalam golongan karbohidrat.

Kandungan gugus fungsi yang telah diketahui dari para peneliti terdahulu, membuktikan bahwa Bioflokulan-DYT adalah senyawa aktif yang dapat berperan sebagai ligan. Ligan tersebut berpotensi untuk dapat berinteraksi melalui pembentukan kompleks dengan larutan ion logam yang umumnya terkandung dalam limbah cair. Untuk mengetahui interaksi pembentukan kompleks dengan larutan ion logam secara komprehensif, maka perlu dilakukan identifikasi lebih lanjut terkait karakteristik sifat fisika dari senyawa aktif Bioflokulan-DYT.

Berdasarkan latar belakang penelitian yang telah dijelaskan sebelumnya, dapat disusun dua tujuan utama pada penelitian ini. Pertama adalah untuk mengisolasi dan mengkristalisasi senyawa aktif Bioflokulan-DYT. Tujuan kedua adalah mengkaji sifat fisika senyawa aktif BioflokulanDYT, berdasarkan pengukuran konduktivitas pada berbagai variasi konsenterasi. Dengan demikian dapat dibuktikan kecenderungan nilai hantaran molar kristal Bioflokulan-DYT, sebagai nilai yang akan mempengaruhi kemampuannya dalam berinteraksi dengan ion logam.

\section{Metodologi Penelitian}

Untuk dapat tercapainya tujuan dari penelitian ini, maka peneliti menggunakan metode eksperimen dengan pendekatan kuantitatif. Sumber data penelitian adalah data primer, yang diperoleh langsung dari objek penelitian, meliputi data konsenterasi dan data hantaran molar. Adapun teknik pengumpulan data penelitian, terdiri atas dua teknik yaitu, teknik kristalisasi Bioflokulan-DYT melalui metode refluks dan teknik pengukuran konduktivitas.

Kristalisasi atau pertumbuhan kristal merupakan metode pemurnian yang sangat penting dalam setiap sintesis senyawa anorganik maupun organik. Menurut Allan (2002), kristalisasi adalah teknik pemisahan dan pemurnian yang digunakan untuk menghasilkan berbagai macam bahan. Secara visual kristalisasi dapat didefinisikan sebagai perubahan fasa di mana produk kristal diperoleh dari suatu larutan. 
Umumnya metoda kristalisasi digunakan untuk pemurnian senyawa-senyawa organik yang berwujud padat pada suhu kamar. Hal ini disebabkan karena zat padat hasil isolasi dari bahan organik jarang didapat dalam bentuk murni. Zat tersebut terkontaminasi oleh zat padat lain yang dihasilkan selama reaksi organik berlangsung. Oleh karena itu, untuk mendapatkan zat padat yang diinginkan, perlu dilakukan pemurnian terlebih dahulu.

Kristalisasi dilakukan dengan cara melarutkan zat organik yang akan dimurnikan ke dalam pelarut dengan suhu mendekati titik didihnya. Kemudian membiarkan zat organik tersebut terpisah dari pelarutnya pada saat proses pendinginan berlangsung. Diperoleh partikel dengan morfologi yang terdefinisi seragam dan mudah larut kembali. Dasar dari proses ini adalah kelarutan suatu zat pada berbagai suhu. Proses kristalisasi dapat berlangsung dengan baik bila pelarut yang dipilih dapat memberikan tingkat kelarutan sedang (10-30).

Senyawa aktif Bioflokulan-DYT diperoleh dalam bentuk kristal murni melalui kristalisasi menggunakan metanol dingin. Pemilihan metanol dingin dilakukan atas dasar kelarutan kristal dalam metanol dingin sangat kecil, sedangkan kelarutan pengotornya cukup besar. Hal ini sesuai dengan data High Performance Liquid Chromatography (HPLC) hasil penelitian Yosanti (2005), yang dapat dilihat pada Gambar 1.

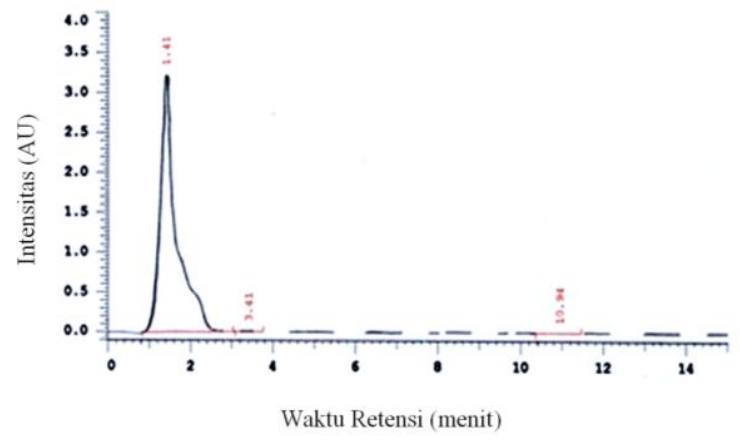

Gambar 1. Kromatogram Kristal BioflokulanDYT dengan Perbandingan Fasa Gerak Air : Metanol $=50 \%: 50 \%$.
Berdasarkan data kromatogram yang ditunjukkan pada gambar 1, dengan fasa gerak air : metanol $=50 \%: 50 \%$ juga diperoleh satu puncak dengan waktu retensi 1.41. Puncak yang terdeteksi pada waktu retensi 3.41 dan 10.94 dianggap sebagai puncak pengotor karena kromatogram tetap sama sampai batas waktu berhentinya. Hasil analisis dengan fasa gerak air $100 \%$, Metanol 100\%, dan air : metanol $=50 \%$ : $50 \%$ hanya dihasilkan satu puncak. Hal ini menunjukkan bahwa kristal bioflokulan DYT tersebut sudah murni.

Pengukuran konduktivitas suatu larutan elektrolit dapat menunjukkan mobilitas dari ionion yang ada dalam larutan. Secara umum kristal Bioflokulan-DYT mengandung gugus-gugus fungsi yang dapat menyebabkan terjadinya ikatan hidrogen dan gaya van der Walls. Apabila kristal bioflokulan DYT dilarutkan dalam air maka kristal tersebut akan menjadi suatu elektrolit yang memiliki daya hantar listrik sehingga dapat terespon oleh konduktometer. Menurut Hendrawati. et. al (2015), nilai konduktivitas yang tinggi dapat terjadi berdasarkan adanya ion-ion mineral dan senyawa organik yang terlarut dalam air. Dengan demikian nilai konduktivitas akan seimbang dengan jumlah zat padat terlarut (garam terlarut). Data konduktivitas hantaran jenis (kappa) yang didapat dinyatakan dalam bentuk hantaran molar $\left(\Lambda_{\mathrm{m}}\right)$, yang secara matematis dirumuskan sebagai berikut:

$\Lambda_{\mathrm{m}}=\frac{\mathrm{K}}{\mathrm{C}}$

Keterangan:

$\Lambda_{\mathrm{m}}=$ Hantaran molar

к $=$ Hantaran jenis (kappa)

$\mathrm{C}=$ Konsentrasi

Sistematika penelitian secara garis besar terdiri dari empat tahap yang meliputi tahapan; preparasi sampel, isolasi senyawa aktif Bioflokulan-DYT, Pemurnian Senyawa Aktif Bioflokulan-DYT, dan uji konduktivitas. Secara 
lebih terperinci keempat tahapan tersebut, dapat dilihat pada Gambar 2.

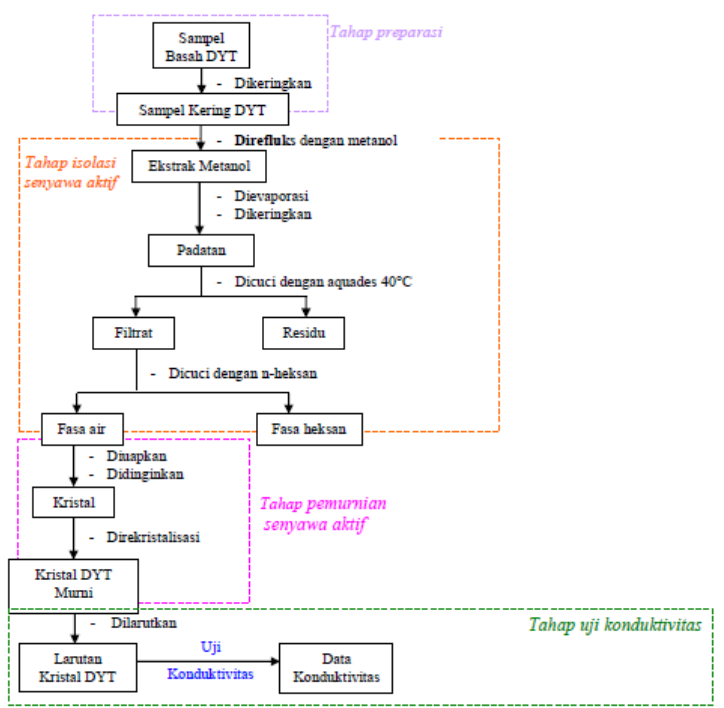

Gambar 2. Bagan Alir Penelitian

Tahap preparasi sampel adalah mempersiapkan sampel basah dengan cara dibersihkan dan dikeringkan di udara terbuka kemudian dihaluskan. Sampel kering yang telah halus kemudian digunakan untuk perlakuan tahap isolasi. Isolasi senyawa aktif Bioflokulan-DYT dilakukan dengan cara merefluks daun menggunakan pelarut metanol. Langkah ini dilanjutkan dengan penghilangan klorofil dan senyawa non polar lainnya. Tahap pemurnian senyawa aktif Bioflokulan-DYT dilakukan dengan cara kristalisasi di dalam pelarut air kemudian direkristalisasi mengunakan pelarut metanol. Pada tahap terakhir yaitu tahap uji konduktivitas, kristal bioflokulan DYT dilarutkan menggunakan pelarut aquades kemudian dilakukan uji konduktivitas dengan menggunakan alat konduktometer merek Consort tipe C830.

\section{Hasil dan Pembahasan}

\section{Preparasi Sampel}

Proses preparasi dimaksudkan untuk mencegah terjadinya kerusakan pada sampel, sehingga diperoleh sampel yang baik untuk digunakan dalam analisis. Sampel basah DYT diperoleh dari daerah Desa Cikaramas Kabupaten Sumedang, dengan massa basah sekitar $22,5 \mathrm{~kg}$. Sampel dibersihkan terlebih dahulu dari berbagai pengotor untuk menghindari kontaminasi yang dapat mengganggu analisis. Kemudian, sampel dikeringkan di udara terbuka pada temperatur kamar. Hal ini dimaksudkan untuk meminalisir kemungkinan terjadinya perubahan kimia. Proses pengeringan dilakukan selama 18 hari. Setelah kering, sampel dihaluskan menggunakan blender sampai berbentuk serbuk. Hal ini dimaksudkan supaya diperoleh sampel dengan luas permukaan yang besar sehingga semakin mempercepat laju ekstraksi. Sampel kering yang telah dihaluskan ditimbang dan didapat sebanyak $6,12 \mathrm{~kg}(27,2 \%$ massa basah).

\section{Isolasi Senyawa Aktif Bioflokulan DYT}

Sampel daun kering direfluks selama tujuh jam menggunakan metanol dengan volume total 45 liter. Digunakannya metanol sebagai pelarut didasarkan pada sifatnya sebagai pelarut universal sehingga diharapkan dapat melarutkan senyawa dengan berbagai kepolaran. Setelah agak dingin, sampel disaring sehingga diperoleh filtrat berwarna hijau tua sebanyak 30,2 liter.

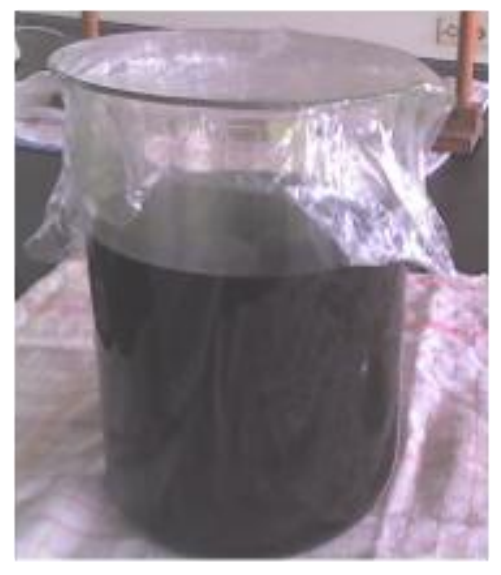

Gambar 3. Filtrat Hasil Refluks

Warna hijau tua filtrat hasil refluks yang diperlihatkan pada Gambar 3, menunjukkan bahwa sebagian besar klorofil telah terekstrak. Keberhasilan ekstraksi berkaitan langsung 
dengan seberapa kuat klorofil tertarik oleh pelarut metanol. Untuk meyakinkan bahwa sebagian besar klorofil telah terekstrak, residu sisa refluks diambil sebagian dan dipanaskan dengan metanol. Filtrat yang dihasilkan berwarna hijau pudar. Dengan demikian dapat dipastikan bahwa sebagian besar senyawa yang akan diisolasi telah terekstrak.

Filtrat hasil refluks kemudian dihilangkan pelarutnya menggunakan rotary evaporator pada suhu $50^{\circ} \mathrm{C}$. Dari hasil evaporasi dihasilkan metanol sebanyak 18 liter dan residu pekat berwarna hijau kecoklatan. Residu ini kemudian dibiarkan mengering untuk menghilangkan metanol yang masih tersisa. Dari pengeringan tersebut diperoleh padatan hijau kecoklatan sebanyak 296,82 gram $(4,85 \%$ dari massa kering).

Tahap selanjutnya yaitu penghilangan klorofil. Klorofil harus dihilangkan karena bukan senyawa yang diinginkan sehingga adanya klorofil dapat menyulitkan proses pemisahan senyawa aktif Bioflokulan-DYT. Penghilangan klorofil dilakukan dengan cara mencucinya menggunakan aquades bersuhu $40^{\circ} \mathrm{C}$ sebanyak $297 \mathrm{~mL}$. Ketika residu padat ditambah aquades, terbentuk larutan berwarna coklat tua dan endapan hijau. Endapan ini kemudian dipisahkan dengan cara disaring sampai tidak adanya residu pada kertas saring. Proses ini

merupakan hal yang sangat penting untuk menghilangkan pengotor terutama klorofil.

Senyawa aktif bioflokulan DYT merupakan senyawa yang bersifat polar. Untuk memisahkan senyawa nonpolar serta klorofil yang masih tersisa dalam fasa air, dilakukan dengan cara ekstraksi cair-cair menggunakan $n$-heksan. Ketika proses ekstraksi berlangsung, konsentrasi senyawa yang terlarut berada dalam kesetimbangan di antara fasa air dan $n$-heksan, sehingga terjadi perbedaan distribusi senyawa tersebut di antara dua fasa, n-heksan merupakan pelarut nonpolar sehingga senyawa yang bersifat nonpolar lebih terdistribusi ke dalam fasa ini, sedangkan senyawa yang bersifat polar akan tetap berada dalam fasa air. Ketika ditambahkan n-heksan, di dalam corong pisah terbentuk dua lapisan. Lapisan air berada di bawah karena massa jenisnya lebih tinggi dari n-heksan. Fasa air berwarna coklat kemerahan sedangkan fasa n-heksan berwarna hijau kekuningan. Hal ini menandakan bahwa klorofil dan senyawa nonpolar lainnya telah terekstrak ke dalam fasa n-heksan. Proses ekstraksi ini dilakukan terusmenerus sampai semua senyawa nonpolar terekstrak ke dalam fasa n-heksan yang ditandai dengan tidak terjadinya perubahan warna pada n-heksan yang ditambahkan ke dalam fasa air. Perbandingan kondisi penambahan n-heksan diawal dan diakhir pada proses ekstraksi caircair diperlihatkan pada Gambar 4.

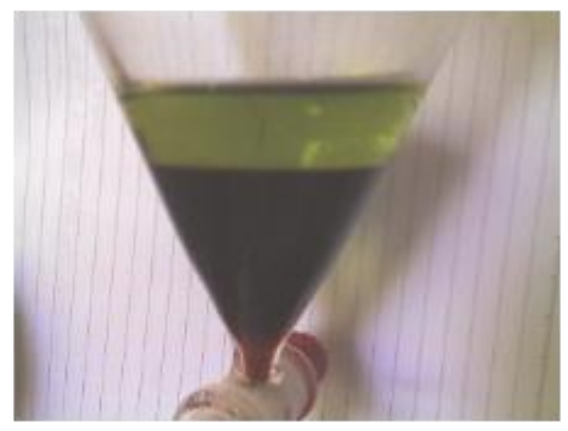

Penambahan n-heksan pertama

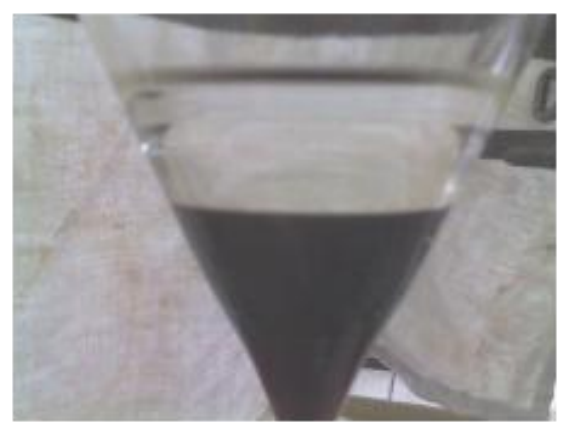

Penambahan n-heksan terakhir

Gambar 4. Proses Ekstraksi Cair-Cair 
Pemurnian Kristal Senyawa Aktif BioflokulanDYT

Fasa air yang diperoleh dari hasil proses ekstraksi cair-cair, diuapkan dan didinginkan. Delapan jam kemudian, terbentuk kristal. Selanjutnya, kristal didiamkan sampai semua pelarutnya menguap. Terbentuknya kristal diawali oleh tercapainya kondisi lewat jenuh ketika larutan didinginkan sehingga poses nukleasi dan pertumbuhan kristal dapat berlangsung secara spontan. Ketika larutan didinginkan, kelarutan senyawa akan berkurang sehingga molekul-molekul polimer yang besar dari senyawa aktif Bioflokulan-DYT, bergabung membentuk suatu agregat yang stabil sehingga inti-inti kristal mulai terbentuk. Proses pembentukan inti ini diduga dipercepat dengan adanya pengotor terlarut pada sampel yang berwarna coklat tua. Molekul pengotor tersebut berperan sebagai pusat inti kristal sehingga meningkatkan kecepatan nukleasi.

Kristal yang dihasilkan pada proses ini masih merupakan kristal kotor yang masih bercampur dengan pengotor, sehingga perlu dilakukan treatment untuk meghilangkan pengotor yang terdapat dalam kristal. Salah satu diantaranya adalah dengan mencuci kristal menggunakan pelarut metanol dingin. Pemisahan kristal dengan pengotornya ini didasarkan pada perbedaan kelarutan antara pengotor dan kristal. Untuk pemilihan pelarut metanol dingin disebabkan kelarutan kristal dalam metanol dingin sangat kecil sedangkan kelarutan pengotornya cukup besar dimana pada suhu rendah, metanol dapat melarutkan sedikit kristal, sedangkan pada suhu mendekati titik didihnya, metanol juga dapat melarutkan kristal lebih banyak.

Setelah penambahan metanol dingin, sebagian besar kristal dapat terpisah dari pengotornya. Namun, sebagian kecil kristal larut dalam metanol dingin sehingga pada pengotor yang telah dipisahkan, terbentuk kembali kristal. Oleh karena itu, pencucian ini dilakukan berulang kali hingga kristal tidak terbentuk lagi pada pengotor. Secara keseluruhan, kristal yang diperoleh sebesar 21,16 gram. Nilai tersebut setara dengan $0,094 \%$ massa basah atau $0,346 \%$ massa kering bahan baku.

Analisis Konduktivitas Kristal Senyawa Aktif Bioflokulan-DYT

Pengukuran konduktivitas kristal senyawa aktif Bioflokulan-DYT, dilakukan pada kondisi suhu konstan yaitu pada suhu kamar $25^{\circ} \mathrm{C}$. Massa kristal bioflokulan DYT yang digunakan pada uji konduktivitas larutan kristal bioflokulan DYT adalah masing-masing sebesar 2 gram. Adapun pengenceran Bioflokulan-DYT menggunakan pelarut air, dilakukan pada berbagai variasi volume pengenceran, $0 \mathrm{ml}, 25$ $\mathrm{ml}, 50 \mathrm{ml}, 75 \mathrm{ml}, 100 \mathrm{ml}, 125 \mathrm{ml}, 150 \mathrm{ml}, 175$ $\mathrm{ml}$ dan $200 \mathrm{ml}$. Hasil pengukuran nilai kappa Bioflokulan-DYT disajikan pada Tabel 1.

Tabel 1. Data Hantaran Jenis (Kappa) dan Hantaran Molar Bioflokulan-DYT pada Berbagai Variasi Konsenterasi

\begin{tabular}{ccc}
\hline $\begin{array}{c}\text { Konsenterasi } \\
\text { Bioflokulan-DYT } \\
(\mathbf{p p m})\end{array}$ & $\begin{array}{c}\text { Kappa } \\
\text { Bioflokulan- } \\
\mathbf{D Y T} \\
(\mathbf{m S})\end{array}$ & $\begin{array}{c}\text { Hantaran } \\
\text { Molar }\end{array}$ \\
$\begin{array}{c}\boldsymbol{\Lambda}_{\mathbf{m}} \\
\left(\mathbf{m S} \mathbf{~ p p m}^{-\mathbf{1}}\right)\end{array}$ \\
\hline 0 & 0,0038 & \\
250 & 0,222 & 0,000888 \\
500 & 0,393 & 0,000786 \\
750 & 0,553 & 0,000737 \\
1000 & 0,688 & 0,000688 \\
1250 & 0,825 & 0,000660 \\
1500 & 0,990 & 0,000666 \\
1750 & 1,100 & 0,000629 \\
2000 & 1,220 & 0,000610 \\
\hline
\end{tabular}

Hasil pengukuran konduktivitas yang disajikan pada tabel 1, memperlihatkan nilai hantaran molar Bioflokulan-DYT tertinggi terdapat pada larutan dengan konsenterasi 2000 ppm yaitu sebesar 1,220 mS. Nilai hantaran jenis terendah adalah 0,222 terdapat pada larutan BioflokulanDYT dengan konsenterasi $250 \mathrm{ppm}$. Untuk pengukuran pada konsentrasi 0 ppm merupakan data nilai hantaran jenis dari pelarut aquades dimana nilai hantaran molarnya tidak dapat dihitung karena didefinisikan sebagai nilai dari 
daya hantar zat terlarut. Didapatnya nilai hantaran jenis aquades ini menunjukan bahwa air walaupun sangat murni, masih dapat menghantarkan listrik.

Hasil perhitungan hantaran molar yang disajikan pada Tabel 1, menunjukkan semakin tinggi nilai konsenterasi, mempengaruhi peningkatan nilai hantaran jenis didukung dengan penelitian sebelumnya (Ginanjar, Hendrawan \& Sonjaya, 2011). Hal ini menandakan jumlah muatan Bioflokulan-DYT terlarut, mengakibatkan kenaikan nilai konduktivitas secara linier. Namun, kenanikan konsenterasi tersebut berbanding terbalik dengan nilai hantaran molar yang semakin menurun. Penurunan ini menandakan ketika konsenterasi ion meningkat, berpotensi mengakibatkan penurunan mobilitas ion yang terdapat pada larutan BioflokulanDYT. Grafik kecenderungan penurunan nilai hantaran molar tersebut, secara lebih jelas dapat dilihat pada Gambar 5.

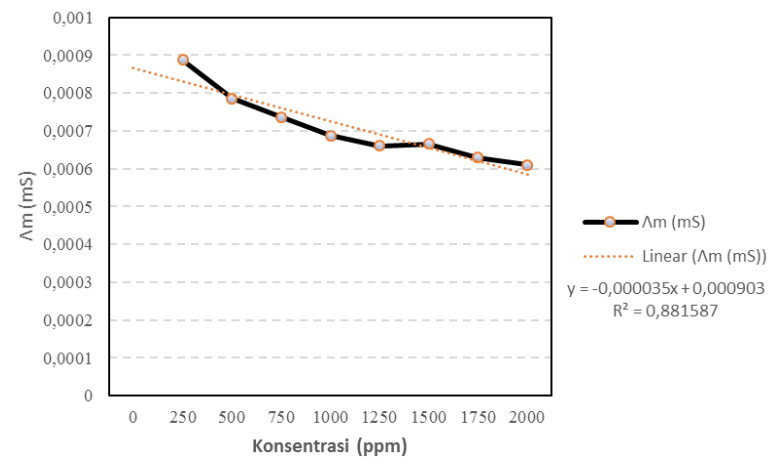

Gambar 5. Grafik Hantaran Molar BioflokulanDYT

Berdasarkan Tabel 1 data nilai hantaran molar Bioflokulan-DYT menunjukan kecenderungan penurunan seiring dengan kenaikan nilai konsentrasi. Penurunan nilai konduktivitas tersebut disebabkan karenan terganggunya mobilitas ion-ion yang terdapat didalam larutan. Kondisi ini berbanding terbalik dengan proses pengenceran larutan elektrolit. Dimana kondisi semakin rendahnya nilai konsentrasi yang diperoleh, mengakibatkan masing-masing ion dari larutan elektorlit tersebut bergerak lebih bebas (Hendrawan dkk, 2016). Hal ini dikarenakan pengaruh ion lawannya akan lebih kecil, akibatnya hantaran molar yang didapat akan mengalami peningkatan.

Penurunan hantaran molar seiring dengan kenaikan konsentrasi sesuai dengan Teori Debye-Huckel. Interpretasi turunnya daya hantar dengan naiknya konsentrasi, disebabkan oleh dua hal yaitu efek relaksasi (relaxation effect) atmosfir ion dan efek elektrophoretik (electrophoretic effect). Hal ini diperkuat dengan pernyataan dari Jain (2007), yang menyatakan bahwa energi potensial suatu ion dalam larutan bergantung pada kekuatan ion larutan. Dalam kasus elektrolit kuat, nilai konduktansi molar pada pengenceran tak terhingga jauh lebih kecil, daripada satu kesatuan yang disebabkan oleh relaxation effect dan electrophoretic effect. Muculnya relaksasi atmosfir ion menurut hukum pembatas Onsager, adalah ketika ion tertarik pada medan listrik, ion tersebut juga akan dipengaruhi gaya berlawanan yang muncul akibat ion atmosfirnya. Kondisi ini akan cenderung menghambat gerak ion tersebut dan akan menurunkan daya hantar ion.

Diperoleh pengaruh konsentrasi terhadap nilai penurunan nilai hantaran molar pada penelitian ini sebesar $88,15 \%$. Nilai tersebut, berdasarkan perhitungan nilai koefisien determinasi yang diperoleh sebesar 0,881587, dengan persamaan regresi liner $\mathrm{y}=0,000903-0,000035 \mathrm{x}$. Dengan demikian terdapat sekitar $11,85 \%$ faktor lain yang berpotensi mempengaruhi nilai hantaran molar.

Potensi nilai hantaran molar Bioflokolan-DYT yang mengalami peningkatan setiap dilakukan pengenceran atau pada penurunan nilai konsenterasi, menandakan senyawa aktif ini berpotensi dapat membentuk ion kompleks pada konsenterasi rendah. Kondisi tersebut diperkuat dengan gugus fungsional seperti gugus $-\mathrm{OH}$, $\mathrm{C}=\mathrm{O}, \mathrm{C}=\mathrm{C},-\mathrm{CH}_{2}$ dan $-\mathrm{CH}_{3}$, yang terkandung pada Bioflokulan-DYT. Dengan demikian 
terindikasi bahwa senyawa aktif BioflokulanDYT dapat berperan sebagai ligan yang dapat berinteraksi dalam pembentukan senyawa kompleks dengan ion logam.

\section{Kesimpulan}

Berdasarkan penelitian yang telah dilakukan, maka dapat diambil beberapa kesimpulan sebagai berikut:

1. Produksi senyawa aktif Bioflokulan-DYT dengan cara merefluk sampel tanaman tropis yang berasal dari daerah Kabupaten Sumedang, dapat menghasilkan kristal sebesar 21,16 gram. Nilai tersebut setara dengan $0,094 \%$ massa basah atau $0,346 \%$ massa kering bahan baku.

2. Diperoleh nilai hantaran molar kristal Bioflokulan-DYT pada berbagai variasi konsenterasi, masing-masing sebesar

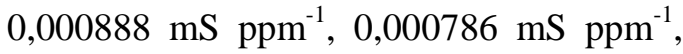
$0,000737 \mathrm{mS} \mathrm{ppm}^{-1}, 0,000688 \mathrm{mS} \mathrm{ppm}{ }^{-1}$, $0,000660 \mathrm{mS} \mathrm{ppm}{ }^{-1}, 0,000666 \mathrm{mS} \mathrm{ppm}{ }^{-1}$, $0,000629 \mathrm{mS} \mathrm{ppm}^{-1}$ dan $0,000610 \mathrm{mS} \mathrm{ppm}^{-1}$.

3. Senyawa aktif Bioflokulan-DYT berpotensi dapat berinteraksi dengan ion logam, sehingga dapat digunakan sebagai pengganti flokulan sintetis dalam proses pengolahan limbah cair.

\section{Daftar Pustaka}

Ahmad, S.M. (2007). Kristalisasi dan Karakterisasi Senyawa Aktif Bioflokulan DYT Hasil Isolasi Melalui Metode Refluks. Skripsi. Universitas Pendidikan Indonesia; Bandung.
Myerson, A. S. (2002). Handbook of Industrial Crystallization. $2^{\text {nd }}$ Ed. Elsevier Inc. , 304 p.

Ginanjar, A., Hendrawan, Sonjaya, Y. (2011). Kajian Termodinamika Interaksi Ligan Bioflokulan DYT terhadap Logam Kobalt (II) melalui Analisis Konduktivitas, Spektrometer UV-VIS dan TGA. Sains dan Teknologi Kimia, 2(1),

Hendrawan, Khoerunnisa, Sonjaya, Y., Rohman, A. (2016). Study of $\mathrm{MgCl} 2$ salt effects on bioflocculant DYT extraction through maceration method. In AIP Conference Proceeding, 1729(1), 020048.

Hendrawati. Sumarni, S., Nurhasni. (2015). Penggunaan Kitosan sebagai Koagulan Alami dalam Perbaikan Kualitas Air Danau. Jurnal Kimia VALENSI, 1 (1), 1-11.

Jain, R. (2007). Physical Chemistry Electrochemistry I. School of Studies in Chemistry Jiwaji University; Gwalior, 41 p.

Walyadi, D. (2008). Kristalisasi dan Karakterisasi Bioflokulan-DYT Bentuk Batang dan Bentuk Kotak. Skripsi. Universitas Pendidikan Indonesia; Bandung.

Yosanti, R.S. (2005). Isolasi dan Karakterisasi Senyawa Aktif Bioflokulan-DYT dengan Sistem Maserasi. Skripsi. Universitas Pendidikan Indonesia; Bandung. 